\title{
Functional requirement of p23 and Hsp90 in telomerase complexes
}

\author{
Shawn E. Holt, ${ }^{1,2}$ Dara L. Aisner, ${ }^{1}$ Joseph Baur, ${ }^{1}$ Valerie M. Tesmer, ${ }^{1}$ Marife Dy, ${ }^{1}$ Michel Ouellette, ${ }^{1}$ \\ James B. Trager, ${ }^{3}$ Gregg B. Morin, ${ }^{3}$ David O. Toft, ${ }^{4}$ Jerry W. Shay, ${ }^{1}$ Woodring E. Wright, ${ }^{1}$ \\ and Michael A. White ${ }^{1,5}$ \\ ${ }^{1}$ Department of Cell Biology and Neuroscience, University of Texas (UT) Southwestern Medical Center, Dallas, Texas \\ 75235 USA; ${ }^{2}$ Departments of Pathology and Human Genetics, Medical College of Virginia/Virginia Commonwealth \\ University, Richmond, Virginia 23998 USA; ${ }^{3}$ Geron Corporation, Menlo Park, California 94025 USA; ${ }^{4}$ Department \\ of Biochemistry and Molecular Biology, Mayo Graduate School, Rochester, Minnesota 55905 USA
}

\begin{abstract}
Most normal human diploid cells have no detectable telomerase; however, expression of the catalytic subunit of telomerase is sufficient to induce telomerase activity and, in many cases, will bypass normal senescence. We and others have previously demonstrated in vitro assembly of active telomerase by combining the purified RNA component with the reverse transcriptase catalytic component synthesized in rabbit reticulocyte extract. Here we show that assembly of active telomerase from in vitro-synthesized components requires the contribution of proteins present in reticulocyte extracts. We have identified the molecular chaperones 23 and Hsp90 as proteins that bind to the catalytic subunit of telomerase. Blockade of this interaction inhibits assembly of active telomerase in vitro. Also, a significant fraction of active telomerase from cell extracts is associated with $\mathbf{p} 23$ and Hsp90. Consistent with in vitro results, inhibition of Hsp90 function in cells blocks assembly of active telomerase. To our knowledge, p23 and Hsp90 are the first telomerase-associated proteins demonstrated to contribute to telomerase activity.
\end{abstract}

[Key Words: Telomerase; telomeres; chaperones; senescence; cancer]

Received November 24, 1998; revised version accepted February 19, 1999.

Telomeres are specialized structures at the ends of linear eukaryotic chromosomes that, in conjunction with the enzyme telomerase, provide a mechanism for maintaining chromosome length. Additional critical functions include protecting chromosome ends from the doublestrand break repair system and mediating chromosome alignment during meiosis (for review, see Blackburn 1995; Kipling 1995). Normal lagging-strand DNA replication fails to copy the ends of linear molecules, leaving a gap between the final RNA priming event and the terminus (Watson 1972; Olovnikov 1973; Wright et al. 1997). In the absence of a compensatory mechanism, this progressive shortening with each cell division ultimately causes proliferative failure. Telomerase provides the enzymatic activity that compensates for this shortening. Vertebrate telomeres are composed of many kilobases of TTAGGG repeats (Moyzis et al. 1988). Telomerase is a ribonucleoprotein that uses the complementary sequence in its associated RNA as a template for a reverse transcription reaction that adds telomeric repeats to the ends of chromosomes (Greider and Blackburn 1989; Feng et al. 1995; Lingner et al. 1997; Meyerson et al. 1997; Nakamura et al. 1997).

${ }^{5}$ Corresponding author.

E-MAIL white08@utsw.swmed.edu; FAX (214) 648-8694.
Telomerase is present in the germ line but is repressed in most human tissues during development (Wright et al. 1996). Although activity can be detected in the adult bone marrow and proliferating epithelial tissues such as skin and the intestine (e.g., Broccoli et al. 1995; Hiyama et al. 1996; Taylor et al. 1996), this activity is not sufficient to maintain telomere length in the progeny of these dividing cells, and telomere shortening is still observed as a function of donor age (Hastie et al. 1990; Lindsey et al. 1991; Vaziri et al. 1993; Hiyama et al. 1996). The telomere shortening observed in vivo correlates with decreased proliferative capacity of cells as a function of donor age (Martin et al. 1970; Schneider and Mitsui 1976), and telomere shortening is also observed as a function of population doublings of cultured cells (Harley et al. 1990; Allsopp et al. 1992), suggesting that telomere shortening might be the mechanism underlying in vitro cellular senescence (Harley 1991). This has now been confirmed by demonstrating that restoring telomerase activity through the exogenous expression of the telomerase catalytic subunit (hTERT) at levels sufficient to maintain or elongate telomeres is sufficient to prevent cellular senescence in a variety of cell types (Bodnar et al. 1998; Vaziri and Benchimol 1998).

The catalytic core of human telomerase has been identified and consists of a reverse transcriptase (hTERT) 
(Meyerson et al. 1997; Nakamura et al. 1997) complexed with the RNA template component (hTR) (Feng et al. 1995). Partially purified native telomerase migrates as a very high molecular weight complex on glycerol gradients, suggesting that it exists as a complex with a variety of other cellular proteins that may regulate assembly of the ribonucleoprotein (RNP) and/or the functional activity of telomerase at the telomere. A protein that interacts with human telomerase, TLP-1, has been identified (Harrington et al. 1997; Nakayama et al. 1997), but its role in the assembly or regulation of telomerase activity is not known and its absence does not influence telomerase activity in vitro (Beattie et al. 1998). To identify telomerase-associated proteins that contribute to the assembly and function of the holoenzyme, we have used the yeast two-hybrid system to isolate hTERT-interacting proteins and studied the requirement of these factors in the assembly of active telomerase in vitro and in vivo. We find that the molecular chaperones p23 and Hsp90 bind to hTERT and are associated with active telomerase in cells. Blocking association of p23 or Hsp90 with hTERT blocks assembly of functional telomerase in vitro and in vivo. Thus, the p23 and Hsp90 interaction with hTERT is required for production of active telomerase. These molecules are, to our knowledge, the first hTERT-associated proteins demonstrated to functionally contribute to telomerase activity.

\section{Results}

Factors present in rabbit reticulocyte lysate are required for assembly of active telomerase in vitro

We and others have demonstrated that in vitro-transcribed and -translated hTERT, together with purified hTR, is sufficient to assemble functional telomerase in vitro (Weinrich et al. 1997; Beattie et al. 1998). It is possible that unknown proteins present in rabbit reticulocyte lysates (RRLs) used to synthesize hTERT associate with hTERT and/or hTR and participate in the production of functional telomerase. To determine if such cofactors are present in RRLs, hTERT synthesized in the absence of hTR was diluted 20-fold in an assembly reaction containing purified hTR together with buffer or increasing amounts of RRL. Following incubation for 90 min, aliquots were removed and assayed for telomerase activity. Little activity was observed when hTERT and hTR were combined in the absence of RRLs; however, the presence of RRLs in the assembly reaction resulted in significant enhancement of detectable telomerase activity (Fig. 1). The telomerase activity in all samples was stable at $30^{\circ} \mathrm{C}$ for at least $6 \mathrm{hr}$, indicating that the reticulocyte lysate does not simply enhance enzyme stability (data not shown). A >100-fold increase in activity was observed when hTERT and hTR were assembled in the highest tested concentration of RRLs (Fig. 1). This stimulation was independent of additional protein synthesis, as the same effect was seen in the presence of cycloheximide (data not shown). Heat-denatured RRLs were incapable of enhancing assembly of telomerase activity, sug-

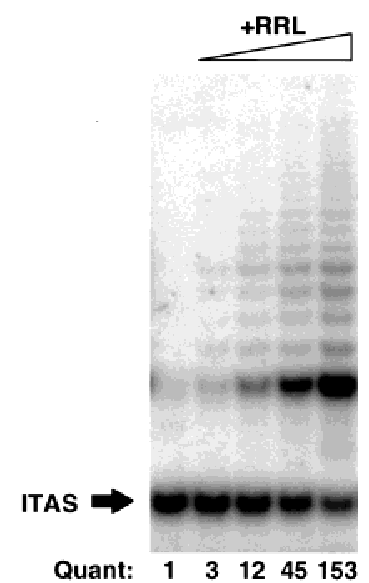

Figure 1. In vitro assembly of active telomerase from hTERT and hTR requires additional components present in reticulocyte lysates. In vitro-transcribed and -translated hTERT was mixed with purified hTR in the presence of increasing concentrations of rabbit reticulocyte lysate $(0,12.5 \%, 25 \%, 37.5 \%$, and $50 \%$ of reaction volume). Following incubation for $90 \mathrm{~min}$ at $30^{\circ} \mathrm{C}$, samples were assayed for telomerase activity by TRAP analysis. The ratio of signal from extended products vs. the 36-bp internal TRAP assay standard (ITAS) was determined by densitometetry analysis. Values shown represent these ratios normalized to that observed in the absence of additional RRLs, which was set at 1 . This experiment has been repeated numerous times with identical results.

gesting that the effects were mediated by proteins /data not shown).

\section{p23 and Hsp90 associate with human telomerase reverse transcriptase}

To identify protein cofactors that contribute to the assembly or activity of telomerase, we used the yeast twohybrid system (Fields and Song 1989) to screen for hTERT-interacting proteins. Expression of hTERT cDNA in yeast did not result in the production of any detectable hTERT protein despite the accumulation of hTERT mRNA (data not shown). This may be due to the presence of a high proportion of codons that require rare yeast tRNAs. We therefore constructed a synthetic coding sequence for hTERT that reflects the codon bias observed in yeast genes. Expression of a synthetic cDNA encoding amino acids 1-195 of hTERT fused to the LexA DNA-binding domain (Vojtek et al. 1993) resulted in readily detectable levels of protein (data not shown). A two-hybrid screen of this bait against a mouse embryo cDNA library (Vojtek et al. 1993) yielded a clone encoding p23 (Fig. 2A). This acidic phosphoprotein associates with Hsp90 in an ATP-dependent manner (Johnson et al. 1994). Together with Hsp90, p23 has been implicated in mediating the formation of receptor/ligand (Hutchison et al. 1995; Pratt and Toft 1997) and protein/RNA (Hu et al. 1997) complexes. The p23 clone did not associate with other 'irrelevant' two-hybrid baits including an $\mathrm{H}$ Ras-LexA fusion and a ralGDS-LexA fusion (data not shown). 


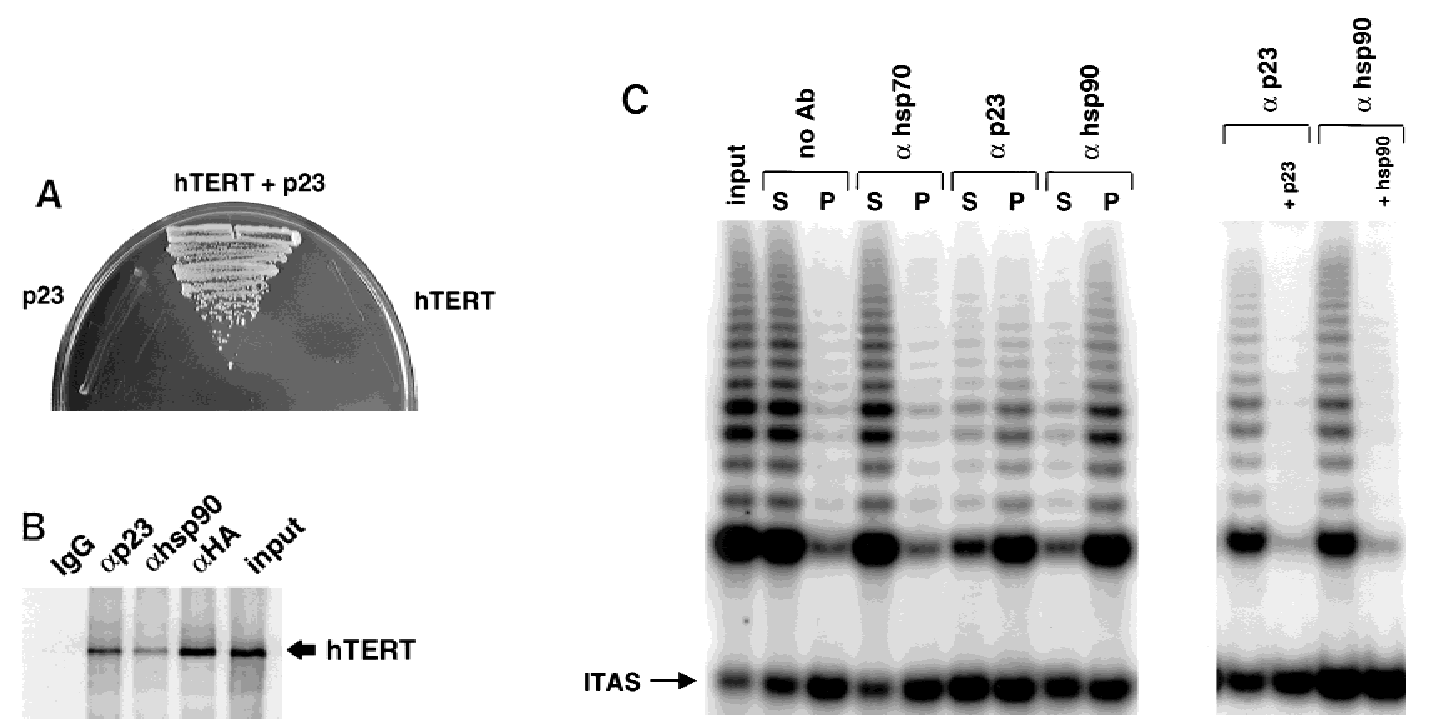

Figure 2. p23 and Hsp90 bind hTERT. (A) Transformants of the yeast two-hybrid reporter strain L40 selected to express LexA-hTERT (1-195) and VP16-p23, alone or together, were tested for the ability to grow on medium lacking histidine. Growth on the selective plate indicates a positive two-hybrid interaction. $(B)$ The indicated antibodies were used to immunoprecipitate proteins from RRLs containing HA-tagged hTERT synthesized with $\left[{ }^{35} \mathrm{~S}\right]$ methionine in the absence of the template RNA. Following extensive washing, the immunoprecipitates were separated by SDS-PAGE, and the presence of coprecipitated hTERT was determined by PhosphorImager analysis. Ten percent of the total translation reaction was loaded to reveal the amount of labeled hTERT present in the reticulocyte lysates. Repeated experiments gave similar results. $(C)$ The indicated antibodies were used to immunoprecipitate proteins from lysates of untransfected HT1080 cells. The immunoprecipitates were washed extensively and assayed for telomerase activity by TRAP. The input lane corresponds to activity present in lysate from 1000 cells. TRAP assays were performed on the pellets $(\mathrm{P})$ and supernatents (S) of immunoprecipitates from lysates of 2000 cells each. Antibodies to p23 and Hsp90 were precoated with saturating levels of purified p23 (+p23) or Hsp90 (+hsp90) to demonstrate specificity of the immunoprecipitation.

Both p23 and Hsp90 are present in RRL, and much of the p23 is bound to Hsp90 (Johnson and Toft 1994). Therefore, we tested for an association of in vitro-transcribed and -translated hTERT with p23 and Hsp90. $\left[{ }^{35} \mathrm{~S}\right]$ Methionine-labeled HA-tagged hTERT was immunoprecipitated with anti-p23, anti-Hsp90, or anti-HA antibodies, demonstrating that full-length hTERT is associated with p23 and Hsp90 in vitro (Fig. 2B). Although $<10 \%$ was associated, this may simply reflect inefficiency of the immunoprecipitation, as the anti-HA antibody was similarly inefficient. The association of hTERT with p23 and Hsp90 did not require the presence of the telomerase template RNA. The relative in vitro telomerase activity in the immunoprecipitations was proportional to the amount of hTERT protein observed in each sample (data not shown).

Next, we investigated the association of p23 and Hsp90 with telomerase activity in cell extracts. HT1080, a human fibrosarcoma cell line, is immortal and expresses active telomerase (Kim et al. 1994). Lysates of HT1080 cells were prepared by sonication in weak detergent. Antibodies to $\mathrm{p} 23$ or Hsp90 bound to agarose beads precipitated telomerase activity from these lysates (Fig. 2C), whereas antibody to the chaperone Hsp70 and a control antibody (MAP1B) (data not shown) failed to precipitate any activity above background levels (Fig. 2C). Preincubation of anti-p23 antibodies with purified p23 prior to incubation with lysates blocked the association of telomerase activity with the precipitates. Simi- larly, incubation of Hsp90 antibodies with purified Hsp90 blocked immunoprecipitation of telomerase activity (Fig. 2C). Quantitation of telomerase activity present in immunoprecipitates from seven experiments performed in parallel showed that anti-p23 immunoprecipitates contained $20 \pm 9 \%$ of input telomerase activity, and anti-Hsp90 precipitates contained $37 \pm 11 \%$ of input. Activity recovered with beads alone, anti-Hsp70, or a control antibody (anti-MAP1) ranged from $2 \%-5 \%$. Thus p23 and Hsp90 appear to be specifically associated with a significant fraction of the active telomerase in cells. Approximately $90 \%$ of the input activity was depleted from the supernatants of anti-p23 and anti-Hsp90 precipitations. Thus, the majority of telomerase in cell lysates may be bound to $\mathrm{p} 23$ and Hsp90. The failure to recover corresponding activity in the immunoprecipitates may be due to losses during wash steps, degredation, or partial inhibition of enzyme activity by precipitation.

\section{p23 participates in assembly of functional telomerase in vitro}

The functional importance of the p23/hTERT association was assessed in telomerase assembly reactions depleted of $\mathrm{p} 23$. Following immunodepletion with anti-p23 antibody precoupled to agarose beads, RRL was severely impaired in its ability to stimulate assembly of active telomerase (Fig. 3A). Addition of purified recombinant 

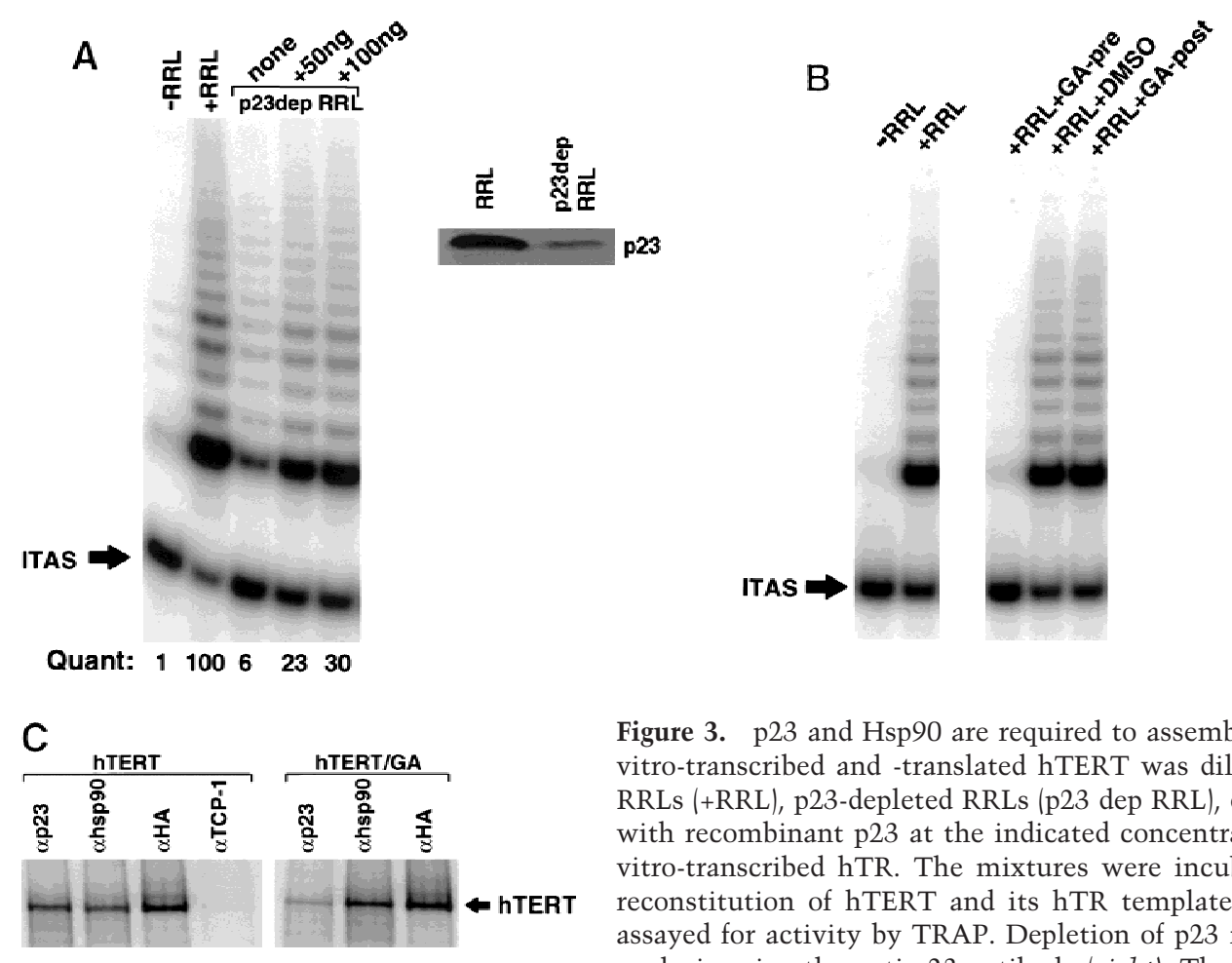
two independent experiments. Quantitation was performed by densitometry analysis as described in Fig. 1. Among many possibilities, failure to fully reconstitute activity with purified p23 may be due to codepletion of p23-associated factors. $(B)$ Telomerase was reconstituted as described in $A$ except that translated hTERT was diluted in RRLs that had been incubated in the presence of geldanamycin (+GA-pre) $(100 \mu \mathrm{g} / \mathrm{ml})$ or DMSO carrier for $30 \mathrm{~min}$. +GA-Post indicates addition of geldanamycin (100 $\mu \mathrm{g} / \mathrm{ml})$ to the TRAP assay after the reconstitution of hTERT and hTR in normal RRLs. Repeated experiments gave identical results. $(C){ }^{35} \mathrm{~S}$-labeled HA-tagged hTERT synthesized in the presence of DMSO carrier (hTERT) or $50 \mu \mathrm{g} / \mathrm{ml}$ geldanamycin (hTERT/GA) was assayed for association with p23 and Hsp90 as described in Fig 1. An antibody to TCP-1, an abundant chaperone, was included as an additional control for specificity.

p23 to the immunodepleted RRL restored activity, demonstrating that $\mathrm{p} 23$ promotes efficient assembly of active telomerase in vitro.

\section{Geldanamycin blocks assembly of active telomerase in vitro}

The benzoquinone ansamysin, geldanamycin, inhibits some functions of Hsp90 by binding to its ATP-binding site, and it also blocks ATP-dependent binding of p23 to Hsp90 (Grenert et al. 1997; Prodromou et al. 1997). Pretreatment of RRLs with geldanamycin completely blocked its ability to enhance assembly of active telomerase (Fig. 3B). Addition of geldanamycin after the assembly step but prior to the telomerase activity assay (Fig. 3B) had no effect; thus, geldanamycin did not inhibit association of fully assembled hTERT/hTR with the substrate primer or inhibit in vitro enzymatic activity. Synthesis of hTERT in the presence of $50 \mu \mathrm{g} / \mathrm{ml}$ geldanamycin resulted in a completely inactive enzyme (data not shown). Although Hsp90 association with hTERT is not affected under these conditions, p23 association is reduced significantly (Fig. 3C), suggesting that Hsp90 may recruit p23 to hTERT complexes. Incubation of
hTERT in geldanamycin after the assembly step did not affect Hsp90 or p23 association with hTERT (data not shown), suggesting that either Hsp90 complexed with p23 and hTERT is inaccessible to geldanamycin or p23 is associated with hTERT independently of Hsp90 once p23 has been recruited to the complex.

\section{Geldanamycin blocks assembly of active telomerase in vivo}

The functional importance of p23 and Hsp90 in telomerase complexes in intact cells was established using geldanamycin to inhibit Hsp90/p23 activity. Telomerase activity in human fibrosarcoma cells (HT1080) is downregulated when the cells become quiescent and is reinduced upon growth stimulation (Holt et al. 1997). Serum-starved, quiescent HT1080 cells with low levels of telomerase activity were treated with serum plus geldanamycin or the carrier DMSO. Cells treated with carrier alone expressed high levels of telomerase activity 24 hr postserum stimulation (Fig. 4A). In contrast, cells treated with geldanamycin at concentrations of $100 \mathrm{ng} /$ $\mathrm{ml}$ or greater failed to express active telomerase in response to serum (Fig. 4A). Consistent with published ob- 

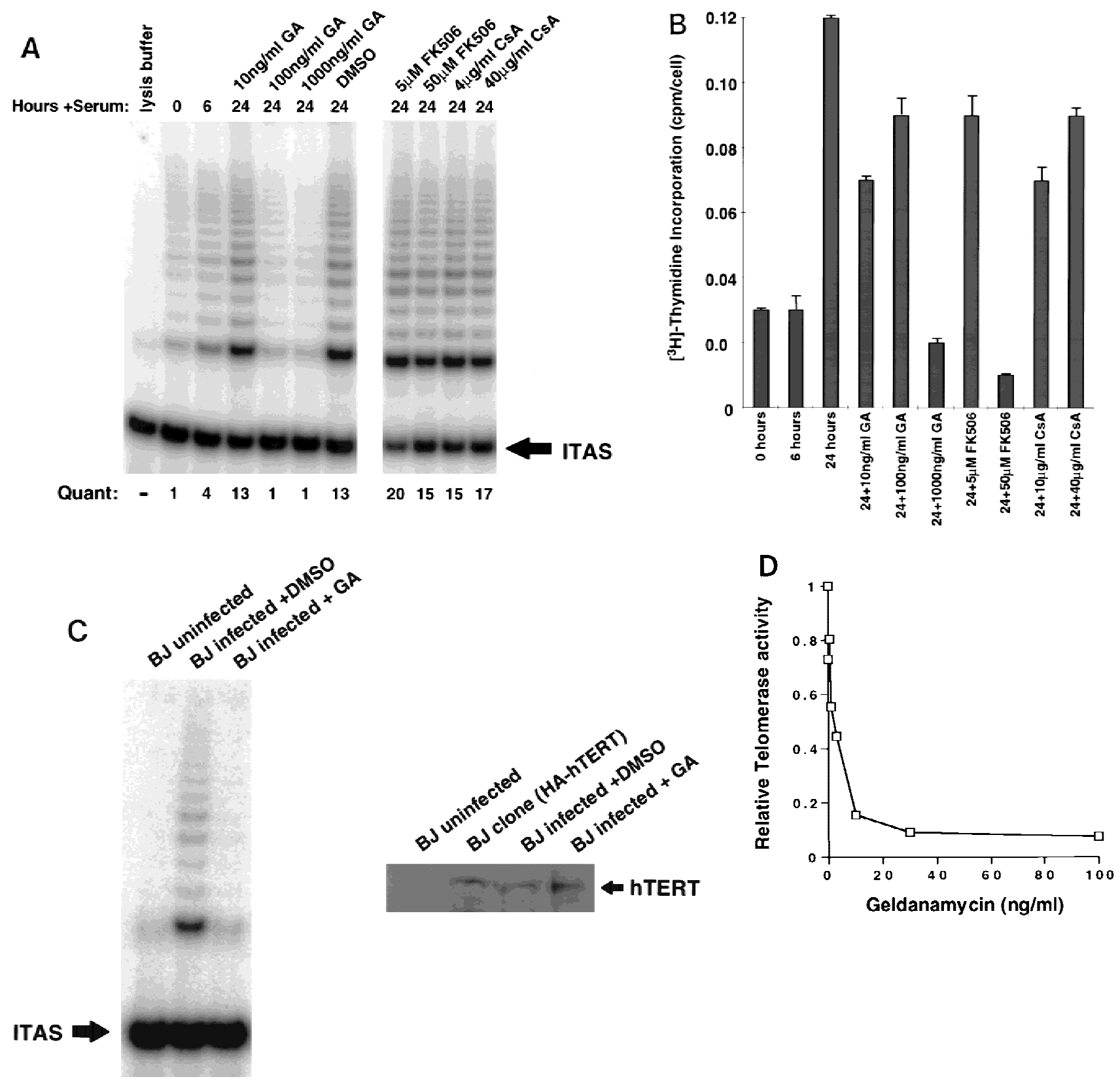

Figure 4. Exposure of cells to an inhibitor of Hsp90 blocks induction of telomerase activity. HT1080 cells were serum starved for 14 days, followed by addition of $10 \%$ serum, together with the indicated concentrations of geldanamycin, DMSO carrier, FK506, or cyclosporin A (CsA). (A) Treated cells were lysed and assayed for telomerase activity by TRAP. Data shown are representative of three independent experiments. (B) Parallel plates were assayed for $\left[{ }^{3} \mathrm{H}\right]$ thymidine incorporation. Effects on plating efficiency were assayed by cell counts before and after stimulation followed by replating. All samples had similar plating efficiencies of $70 \%-80 \%$ except for treatment with $40 \mu \mathrm{g} / \mathrm{ml}$ of CsA, which reduced plating efficiencies to $60 \%$ (data not shown). (C) Telomerase negative primary human fibroblasts (BJ cells) were infected with retrovirus expressing HA-tagged hTERT. Four hours postinfection, cells were incubated with $100 \mathrm{ng} / \mathrm{ml}$ geldanamycin; $24 \mathrm{hr}$ postinfection, cells were harvested and assayed for telomerase activity by TRAP analysis and expression of the HA-tagged hTERT by Western analysis using the anti-HA (12CA5) antibody. Lysates from a selected population of BJ cells expressing HA-tagged hTERT were used as a positive control for the Western analysis. $(D)$ Cells were treated as described in $C$ with a range of concentrations of geldanamycin. TRAP activity following treatment was quantitated as in Fig 1 . Values plotted are the average of two experiments.

servations, concentrations of geldanamycin required to inhibit Hsp90 in cells are 1000-fold less than those required to inhibit Hsp90 in vitro (Hu and Seeger 1996). Geldanamycin blocked induction of telomerase activity at concentrations that did not affect S-phase entry or short-term viability (Fig. 4B; data not shown). p23 and Hsp90 have been reported to exist in complexes containing one or more immunophilins including FK506-bind- 
ing proteins and cyclosporin A binding protein (Freeman et al. 1996; Pratt and Toft 1997). Incubation of HT1080 cells with FK506 or cyclosporin, even at concentrations that blocked induction of DNA synthesis, or that were moderately toxic over the 24-hr incubation (Fig. 4B), did not affect the induction of telomerase activity (Fig. 4A). These results are consistent with a requirement for p23 and Hsp90 but not immunophilin function for induction of active telomerase in vivo.

We also tested if geldanamycin treatment blocked activity of ectopically expressed HA-tagged hTERT under control of a retroviral promoter. Primary human fibroblasts (BJ) contain no detectable telomerase activity (Bodnar et al. 1998). These cells express hTR but not hTERT (Nakamura et al. 1997). Infection of BJ cells with retrovirus expressing HA-tagged hTERT results in induction of telomerase activity by $24 \mathrm{hr}$ postinfection (Fig. 4C). Treatment of BJ cells with geldanamycin $4 \mathrm{hr}$ after infection with hTERT retrovirus inhibited production of detectable telomerase activity $24 \mathrm{hr}$ later. Incubation in geldanamycin did not block expression of the HA-tagged hTERT (Fig. 4C). The minimal dose of geldanamycin required to inhibit production of active telomerase in the infected BJ cells was <10 ng/ml (Fig. 4D).

\section{Purified recombinant components of a 'foldosome' complex mediate telomerase assembly in vitro}

p23 has been studied extensively for its role in stabilizing steroid receptors in a conformation competent to associate with ligand (for review, see Pratt and Toft 1997). Glucocorticoid receptor reconstitution studies have demonstrated the sufficiency of a group of purified chaperone proteins to mediate a multistep complex formation that results in a functionally active receptor. These proteins include Hsp90, p23, Hsp70, Hop (보 $\underline{\text { organiz- }}$ ing protein), and Hsp40 (Dittmar et al. 1997). Hsp90 and p23, but not Hsp70, Hop, or Hsp40, remain stoichiometricly associated with glucocorticoid receptors prior to ligand binding. However, Hsp70, HOP, and Hsp40 are required to allow association of Hsp90 and p23 with the receptor (Dittmar et al. 1997, 1998). A similar 'foldosome' activity has been described for the progesterone receptor (Kosano et al. 1998). Substitution of purified Hsp90 and p23 for RRL in an in vitro telomerase assembly reaction did not enhance the production of active telomerase (data not shown). However, when Hsp70, Hop, and Ydj-1 [the yeast homolog of Hsp40 (Caplan et al. 1992) were added to the assembly reaction in addition to Hsp90 and p23, levels of telomerase activity were obtained that were comparable to that resulting from assembly reactions containing RRLs (Fig. 5). Dropping out any single protein resulted in decreased levels of telomerase activity (data not shown), suggesting that these molecules are core to a minimally sufficient telomerase assembly reaction.

\section{Discussion}

The reverse transcriptase catalytic core (hTERT) (Meyerson et al. 1997; Nakamura et al. 1997) and the RNA

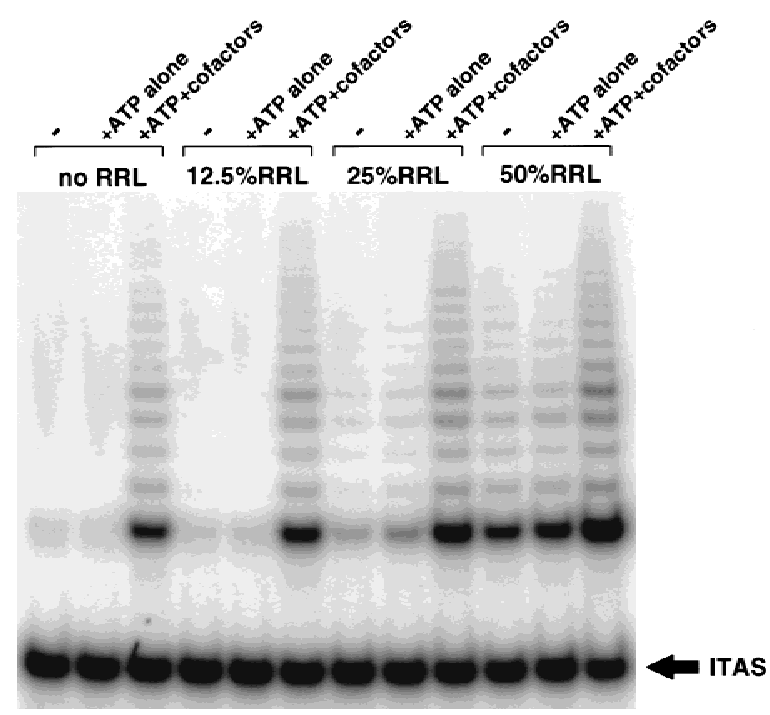

Figure 5. Purified foldosome components substitute for RRLs to assemble active telomerase in vitro. In vitro-transcribed and -translated hTERT was diluted $1 / 20$ into an assembly reaction containing purified hTR and buffer in the absence $(-)$ or presence (+ATP alone) of $5 \mathrm{~mm} \mathrm{ATP}$, or in the presence of 5 mMATP and purified foldosome components: p23, Hsp90, Hop, Hsp70, YDI1 (+ATP+cofactors). Identical assembly reactions contained increasing concentrations of RRLs. All reactions were incubated for $90 \mathrm{~min}$ at $30^{\circ} \mathrm{C}$ followed by TRAP analysis. The experiment shown is representative of three independent experiments.

template (hTR) (Feng et al. 1995) components of human telomerase have been cloned. These two components, together with previously unidentified factors present in RRLs are sufficient to assemble active telomerase in vitro (Weinrich et al. 1997; Beattie et al. 1998; this work). To identify the cofactors required to assemble functional telomerase, we screened for hTERT-interacting proteins using the yeast two-hybrid system. From a screen using the amino terminus of hTERT (amino acids 1-195), we identified chaperone $\mathrm{p} 23$ as a telomerase-interacting protein. p23 was found to be associated with hTERT proteins synthesized in vitro and functions coordinately with Hsp90 in cells, to which it binds in an ATP-dependent manner (for review, see Toft 1998). Like p23, Hsp90 was found to be associated with hTERT proteins synthesized in vitro. The functional importance of these interactions was revealed by the observation that the presence of p23 and Hsp90 in RRLs was required for assembly of functional telomerase from in vitro-synthesized components.

p23 was first identified as a component of progesterone and glucocorticoid receptor complexes (Johnson et al. 1994; Hutchison et al. 1995). Subsequently, it was found that p23 is associated with Hsp90 in these complexes and that the presence of both molecules is required to maintain these receptors in a high-affinity ligand binding state (Hutchison et al. 1995; Johnson and Toft 1995). A series of studies examining complex formation revealed that it was a multistep process involving additional transiently associated chaperones; Hsp70, Hop, and Hsp40 
(Dittmar and Pratt 1997; Dittmar et al. 1997, 1998). These observations led to the concept of a molecular chaperone machine or foldosome that mediates assembly of a biologically active protein complex. Our observations suggest that a similar foldosome functions to assemble active telomerase. Purified recombinant foldosome components substituted for the requirement of RRLs in telomerase assembly reactions. A similar activity is most likely present in vivo, as geldanamycin, a specific inhibitor of Hsp90 (Toft 1998), blocked induction of native telomerase activity in fibrosarcoma cells, and blocked the activity of ectopically expressed hTERT in normal human fibroblasts.

We find that a significant fraction of telomerase activity from cells can be immunoprecipitated with antibodies against p23 or Hsp90. Geldanamycin, an Hsp90 inhibitor, blocks assembly of active telomerase in vivo. These observations, coupled with the in vitro data described above, strongly suggest that p23 and Hsp90 are associated with telomerase in cells and are required to produce functional telomerase at least at the level of assembly of the RNP. The apparent continued association of p23 and Hsp90 with a significant portion of active enzyme from cells hints that these molecules may have a role in telomerase activity in postassembly steps. We do not suspect that $\mathrm{p} 23$ and Hsp90 are required for the reverse transcriptase activity of telomerase as measured in vitro by telomerase repeat amplification protocol (TRAP). Preliminary experiments suggest that stripping p23 and Hsp90 from telomerase after assembly of the RNP does not affect the activity of the RNP in vitro (data not shown). However, by analogy to the contribution of Hsp90 and p23 to steroid receptor function, it is tempting to speculate that p23 and Hsp90 mediate conformational changes in the enzyme that may occur during the translocation step, in which telomerase pauses and repositions itself after the addition of every six nucleotides (Morin 1989).

Our observations are in striking parallel to those made with another protein known to associate with p23; hepadnavirus reverse transcriptase (Hu and Seeger 1996; Hu et al. 1997). p23 and Hsp90 are required for the activity of this reverse transcriptase and are stably incorporated into nucleocapsids. The association of hepadnavirus reverse transcriptase with p23 is required for association with its RNA template (Hu and Seeger 1996; Hu et al. 1997). We have found no evidence that p23 and Hsp90 are required to allow physical association of hTERT with $\mathrm{hTR}$, but they may be required to allow functional association (V.M. Tesmer, unpubl.).

In summary, we have identified p23 and Hsp90 as two proteins that are physically and functionally associated with telomerase activity. p23 and Hsp90 bind to hTERT and promote the assembly of active telomerase in vitro and in cells. In addition, these molecules appear to be components of the active holoenzyme and could have important functional roles in telomerase action. Future studies will be directed at determining the role of p23 and Hsp90 in the catalytic activity of telomerase and telomere biogenesis as it impacts cell aging and cancer.

\section{Materials and methods}

Plasmids

A gene encoding the amino-terminal 195 residues of hTERT with codon usage optimized for expression in Saccharomyces cerevisiae was assembled from six oligonucleotide pairs (HHMI/Keck Oligonucleotide Facility, Yale University), the ends of which were staggered by 10 bases to create complementary sequences for ligation. The oligonucleotides were gel purified; pairs were annealed by heating to $100^{\circ} \mathrm{C}$ for $10 \mathrm{~min}$, at $90^{\circ} \mathrm{C}$ for $10 \mathrm{~min}$, and chilled rapidly. The full-length construct (pJBT1) was built by sequential ligation of adjoining pairs; the ligated fragments were gel-purified prior to each subsequent ligation; the final product was subcloned into pJBT0, a modified form of pBluescript II-SK+ (Stratagene). The BamHI-SalI fragment of pJBT1 was inserted into pBTM116 (Vojtek et al. 1993) to create the bait encoding the first 195 amino acids of hTERT. For in vitro expression, the human hTERT cDNA was inserted into pcDNA3/HisC (Invitrogen) in-frame with three tandem copies of a carboxy-terminal HA epitope. To produce a retroviral construct, this same cDNA was inserted into pBABE Puro (Morgenstern and Land 1990) as an EcoRI-SalI fragment. pTRC3 and pGEM-U2 were described previously (Weinrich et al. 1997).

\section{Antibodies and chemicals}

Monoclonal anti-HA antibody (12CA5) was purchased from Boehringer Mannheim. Monoclonal anti-p23 (JJ3), anti-Hsp90 (H9010), and anti-Hsp70 antibodies were described previously (Johnson et al. 1994; Barent et al. 1998). Monoclonal antiMAP1B antibody was a gift from G. Bloom (University of Texas Southwestern Medical Center). Monoclonal TCP-1 was purchased from Stressgen, and normal mouse IgG was purchased from Santa Cruz Biotechnology. Geldanamycin was purchased from Calbiochem. FK506 was a gift from Fujisawa USA, and cyclosporin A was purchased from Sigma.

\section{Proteins}

hTERT was synthesized in the RRL system (TNT, Promega) as described previously (Weinrich et al. 1997) in the presence of $\left[{ }^{35} \mathrm{~S}\right]$ methionine. Human Hsp90 $\beta$ was expressed in SF9 cells and purified to $>99 \%$ homogeneity, as described previously (Sullivan et al. 1997). Human p23, human Hop, and ydj-1p were expressed in Escherichia coli and purified as described previously (Caplan et al. 1992; Johnson and Tofts 1994; Schumacher et al. 1994). Human Hsp70 was expressed in SF9 cells and purified as described previously for avian Hsp70 (Schumacher et al. 1996) to $>97 \%$ homogeneity.

\section{Yeast two-hybrid analysis}

Yeast two-hybrid screens were carried out using the LexA-dependent reporter strain L40 and a size-selected 16-day mouse embryo library as described (Vojtek et al. 1993).

\section{In vitro telomerase assembly}

hTR was produced with the Megascript T7 in vitro transcription system (Ambion). To assemble active telomerase $0.2 \mu \mathrm{l}$ of in vitro-transcribed and -translated hTERT and $0.5 \mu \mathrm{g}$ of hTR were mixed together in a $4 \mu \mathrm{l}$ assembly assay with or without additional fresh RRL and incubated at $30^{\circ} \mathrm{C}$ for $90 \mathrm{~min}$. Immunodepletion of RRLs with anti-p23 was performed as described previously (Johnson and Tofts 1994). To assemble telomerase with purified cofactors, hTERT and hTR, as above, were mixed 
with $500 \mathrm{ng}$ of p23, $750 \mathrm{ng}$ of Hsp90, $125 \mathrm{ng}$ of Hsp70, $25 \mathrm{ng}$ of Hop (p60), and $25 \mathrm{ng}$ of YDJ-1 in the presence of $5 \mathrm{~mm} \mathrm{ATP,} 10$ $\mathrm{mm}$ Tris- $\mathrm{HCl}, 50 \mathrm{~mm} \mathrm{KCl}, 5 \mathrm{~mm} \mathrm{MgCl}_{2}$ and $2 \mathrm{~mm}$ DTT (pH 7.5) in a total volume of $5 \mu \mathrm{l}$.

\section{Telomerase activity assays}

Telomerase activity in all samples was determined by TRAP, as described previously (Weinrich et al. 1997), with minor modifications. The TRAP-eze Telomerase Detection Kit (Intergen), which includes a 36-bp internal standard to allow quantitation of activity, was used as suggested by the manufacturer. After telomerase extension for $30 \mathrm{~min}$ at room temperature, extended products were amplified by a two-step PCR $\left(94^{\circ} \mathrm{C}\right.$ for $30 \mathrm{sec}$, $60^{\circ} \mathrm{C}$ for $30 \mathrm{sec}$ ) for 27 cycles. Products were separated on $10 \%$ polyacrylamide gels and exposed to PhosphorImager screens. Quantitative estimates of telomerase activity were calculated by determining the ratio of the 36-bp internal standard to the 6-bp telomerase-specific ladder (Holt et al. 1997).

\section{Immunoprecipitations}

For immunoprecipitation from in vitro assembly reactions, antibodies were added to a final concentration of $0.5 \mu \mathrm{g} / \mathrm{ml}$ and incubated for $1 \mathrm{hr}$ on ice. Protein G-agarose (Boehringer Mannheim) was added, and the mixture was incubated at $4^{\circ} \mathrm{C}$ for an additional hour with constant rotation. Agarose pellets were subsequently washed three times with $20 \mathrm{mM}$ HEPES (pH 7.6), $20 \%$ glycerol, $100 \mathrm{~mm} \mathrm{NaCl}, 0.2 \mathrm{~mm}$ EGTA, $1 \mathrm{~mm} \mathrm{MgCl} 2,0.1 \%$ NP-40, and $0.1 \%$ BSA. To detect proteins, washed pellets were heated to $80^{\circ} \mathrm{C}$ for $10 \mathrm{~min}$ and electrophoresed by SDS-PAGE $(7.5 \%)$; dried gels were exposed to a PhosphorImager screen (Molecular Dynamics) for 24-48 hr. For immunoprecipitations from cell lysates, HT1080 cells were suspended at a concentration of 1000 cells/ $\mathrm{\mu l}$ in lysis buffer $[0.01 \% \mathrm{NP}-40,10 \mathrm{~mm}$ Tris at $\mathrm{pH}$ 7.5, $50 \mathrm{~mm} \mathrm{KCl}, 5 \mathrm{~mm} \mathrm{MgCl}_{2}, 2 \mathrm{~mm} \mathrm{DTT}, 20 \%$ glycerol plus protease inhibitors (CompleteMini EDTA free, Boehringher Mannheim)] and incubated on ice for $20 \mathrm{~min}$ followed by a 5 -sec pulse of sonication at $50 \mathrm{~J} /$ Watt-sec. Lysates were then spun at 13,000 rpm for $15 \mathrm{~min}$, and resulting supernatants used for immunoprecipitation. Approximately $16 \mu \mathrm{g}$ of each antibody was precoupled to $8 \mu \mathrm{l}$ of a $50 \%$ slurry of protein-G agarose beads by incubating for $1 \mathrm{hr}$ at $4^{\circ} \mathrm{C}$ with constant rotation. Antibodycoated beads were washed extensively with lysis buffer prior to use in immunoprecipitation reactions. Four microliters of cell lysate and $16 \mu$ of $5 \%$ BSA (in lysis buffer) were combined with antibody-beads and rotated for $1 \mathrm{hr}$ at $4^{\circ} \mathrm{C}$. Immunoprecipitations were then washed with the lysis buffer $4 \times 350 \mu$ for $5 \mathrm{~min}$ with rotation at $4^{\circ} \mathrm{C}$. For TRAP assays following immunoprecipitations, protein $\mathrm{G}$-agarose pellets were resuspended in a final volume of $8 \mu \mathrm{l}$ with lysis buffer and $2 \mu \mathrm{l}$ removed for TRAP assays as described.

\section{Production of retroviral stocks}

pBABE Puro containing HA-tagged hTERT was transfected into PE501 cells (Morgenstern and Land 1990) by electroporation. Transfected cells were selected $48 \mathrm{hr}$ post-transfection with 5 $\mu \mathrm{g} / \mathrm{ml}$ puromycin. Supernatant from selected cells was harvested, filtered, and placed onto subconfluent PA317 cells. Infected PA317 cells were selected for $48 \mathrm{hr}$ postinfection by addition of $5 \mu \mathrm{g} / \mathrm{ml}$ puromycin. Supernatants from selected cells were harvested, filtered, and frozen in aliquots at $-80^{\circ} \mathrm{C}$.

\section{Cell lines and culture conditions}

HT1080 cells were cultured as described previously (Holt et al.
1997). To test the effects of drugs on telomerase activity, cells were incubated in the absence of serum for 7 days. Serum was then added back to the cultures with one of the following additions: DMSO, geldanamycin, FK506 (gift from Fujisawa USA, Inc.), or cyclosporin A (Sigma), for $24 \mathrm{hr}$. $\left[{ }^{3} \mathrm{H}\right]$ Thymidine incorporation was performed as described (Holt et al. 1996). BJ fibroblasts were infected with the hTERT-HA3-containing retrovirus and selected with puromycin to produce a stable population of cells expressing HA-tagged telomerase. For transient expression of hTERT-HA3 in BJ fibroblasts, cells were split into $15-\mathrm{cm}$ dishes at low density 2 days prior to experiment. Retroviral supernatants were thawed at $37^{\circ} \mathrm{C}$ and placed on plated cells in the presence of $4 \mu \mathrm{g} / \mathrm{ml}$ Polybrene. Four hours after infection, cells were treated with geldanamycin (Calbiochem) or mock treated, and incubated for an additional $20 \mathrm{hr}$.

\section{Acknowledgments}

We thank Nancy McMahon and Bridget Stensgard for protein purification, and Bryan Frank, Barbara Lastelic, and Mike Lombaredi for technical assistance. We also thank the assistance of UT Southwestern Dermatology Research sequencing core facility. This research was supported by grants from the Welch Foundation (M.A.W.), National Institutes of Health (NIH, AG07992) (J.W.S. and W.E.W.), and Geron Corporation. S.E.H. is a National Institute of Aging fellow, and V.M.T. is supported by a NIH oncology training grant.

The publication costs of this article were defrayed in part by payment of page charges. This article must therefore be hereby marked 'advertisement' in accordance with 18 USC section 1734 solely to indicate this fact.

\section{References}

Allsopp, R.C., H. Vaziri, C. Patterson, S. Goldstein, E.V. Younglai, A.B. Futcher, C.W. Greider, and C.B. Harley. 1992. Telomere length predicts replicative capacity of human fibroblasts. Proc. Nat1. Acad. Sci. 89: 10114-10118.

Barent, R.L., S.C. Nair, D.C. Carr, Y. Ruan, R.A. Rimerman, J. Fulton, Y. Zhang, and D.F. Smith. 1998. Analysis of FKBP51/ FKBP52 chimeras and mutants for hsp90 binding and association with progesterone receptor complexes. Mol. Endocrinol. 12: 342-354.

Beattie, T.L., W. Zhou, M. Robinson, and L. Harrington. 1998. Reconstitution of human telomerase in vitro. Curr. Biol. 8: $177-180$.

Blackburn, E.H. 1995. Telomeres. Cold Spring Harbor Laboratory Press, Cold Spring Harbor, NY.

Bodnar, A.G., M. Ouellette, M. Frolkis, S.E. Holt, C.-P. Chu, G.B. Morin, C.B. Harley, J.W. Shay, S. Lichtsteiner, and W.E. Wright. 1998. Extension of life-span by introduction of telomerase into normal human cells. Science 279: 349-352.

Broccoli, D., J.W. Young, and T. de Lange. 1995. Telomerase activity in normal and malignant hematopoietic cells. Proc. Nat1. Acad. Sci. 92: 9082-9086.

Caplan, A.J., J. Tsai, P.J. Casey, and M.G. Douglas. 1992. Farnesylation of YDJ1p is required for function at elevated growth temperatures in Saccharomyces cerevisiae. I. Biol. Chem. 267: 18890-18895.

Dittmar, K.D. and W.B. Pratt. 1997. Folding of the glucocorticoid receptor by the reconstituted hsp90-based chaperone machinery. J. Biol. Chem. 272: 13047-13054.

Dittmar, K.D., D.R. Demady, L.F. Stancato, P. Krishna, and W.B. Pratt. 1997. Folding of the glucocorticoid receptor by 
the heat shock protein (hsp) 90-based chaperone machinery. J. Biol. Chem. 272: 21213-21220.

Dittmar, K.D., M. Banach, M.D. Galigniana, and W.B. Pratt. 1998. The role of DnaJ-like proteins in glucocorticoid receptor-hsp90 heterocomplex assembly by the reconstituted hsp90-p60-hsp70 foldosome complex. J. Biol. Chem. 273: 7358-7368.

Feng, J., W.D. Funk, S.S. Wang, S.L. Weinrich, A.A. Avilion, C.P. Chiu, R.R. Adams, E. Chang, R.C. Allsopp, J. Yu, S. Le, M.D. West, C.B. Harley, W.H. Andrews, C.W. Greider, and B. Villeponteau. 1995. The RNA component of human telomerase. Science 269: 1236-1239.

Fields, S. and O. Song. 1989. A novel genetic system to detect protein-protein interactions. Nature 340: 245-246.

Freeman, B.C., D.O. Toft, and R.I. Morimoto. 1996. Molecular chaperone machines: chaperone activities of the cyclophilin Cyp-40 and the steroid aporeceptor-associated protein p23. Science 274: 1718-1720.

Greider, C.W. and E.H. Blackburn. 1989. A telomeric sequence in the RNA of Tetrahymena telomerase required for telomere repeat synthesis. Nature 337: 331-337.

Grenert, J.P., W.P. Sullivan, P. Fadden, T.A.J. Haystead, J. Clark, E. Mimnaugh, H. Krutzsch, H.-J. Ochel, T.W. Schulte, E. Sausville, L.M. Neckers, and D.O. Toft. 1997. The aminoterminal domain of heat shock protein 90 (hsp90) that binds geldanamycin is an ATP/ADP switch domain that regulates hsp90 conformation. J. Biol. Chem. 272: 23843-23850.

Harley, C.B. 1991. Telomere loss: Mitotic clock or genetic time bomb? Mutat. Res. 256: 271-282.

Harley, C.B., A.B. Futcher, and C.W. Greider. 1990. Telomeres shorten during aging. Nature 345: 458-460.

Harrington, L., T. McPhail, V. Mar, W. Zhou, R. Oulton, M.B. Bass, I. Arruda, and M.O. Robinson. 1997. A mammalian telomerase-associated protein. Science 275: 973-977.

Hastie, N.D., M. Dempster, M.G. Dunlop, A.M. Thompson, D.K. Green, and R.C. Allshire. 1990. Telomere reduction in human colorectal carcinoma and with ageing. Nature 346: 866-868.

Hiyama, E., K. Hiyama, N. Tatsumoto, T. Kodama, J.W. Shay, and T. Yokoyama. 1996. Telomerase activity in human intestine. Int. J. Oncol. 9: 453-458.

Holt, S.E., W.E. Wright, and J.W. Shay. 1996. Regulation of telomerase activity in immortal cell lines. Mol. Cell. Biol. 16: 2932-2939.

Holt, S.E., D.L. Aisner, J.W. Shay, and W.E. Wright. 1997. Lack of cell cycle regulation of telomerase activity in human cells. Proc. Natl. Acad. Sci. 94: 10687-10692.

$\mathrm{Hu}, \mathrm{J}$. and C. Seeger. 1996. Hsp90 is required for the activity of a hepatitis B virus reverse transcriptase. Proc. Natl. Acad. Sci. 93: 1060-1064.

Hu, J., D.O. Toft, and C. Seeger. 1997. Hepadnavirus assembly and reverse transcription require a multi-component chaperone complex which is incorporated into nucleocapsids. EMBO T. 16: 59-68.

Hutchison, K.A., L.F. Stancato, J.K. Owens-Grillo, J.L. Johnson, P. Krishna, D.O. Toft, and W.B. Pratt. 1995. The 23-kDa acidic protein in reticulocyte lysate is the weakly bound component of the hsp foldosome that is required for assembly of the glucocorticoid receptor into a functional heterocomplex with hsp90. J. Biol. Chem. 270: 18841-18847.

Johnson, J.L. and D.O. Toft. 1994. A novel chaperone complex for steroid receptors involving heat shock proteins, immunophilins, and p23. J. Biol. Chem. 269: 24989-24993.

. 1995. Binding of p23 and hsp90 during assembly with the progesterone receptor. Mol. Endocrinol. 10: 670-678.

Johnson, J.L., T.G. Beito, C.J. Krco, and D.O. Toft. 1994. Char- acterization of a novel 23-kilodalton protein of unactive progesterone receptor complexes. Mol. Cell. Biol. 14: 1956-1963.

Kim, N.W., M.A. Piatyszek, K.R. Prowse, C.B. Harley, M.D. West, P.L. Ho, G.M. Coviello, W.E. Wright, S.L. Weinrich, and J.W. Shay. 1994. Specific association of human telomerase activity with immortal cells and cancer. Science 266: 2011-2015.

Kipling, D. 1995. The telomere. Oxford University Press, New York, NY.

Kosano, H., B. Stensgaard, M.C. Charlesworth, N. McMahon, and D. Toft. 1998. The assembly of progesterone receptorhsp90 complexes using purified proteins. J. Biol. Chem. 273: 32973-32979.

Lindsey, J., N.I. McGill, L.A. Lindsey, D.K. Green, and H.J. Cooke. 1991. In vivo loss of telomeric repeats with age in humans. Mutat. Res. 256: 45-48.

Lingner, J., T.R. Hughes, A. Shevchenko, M. Mann, V. Lundblad, and T.R. Cech. 1997. Reverse transcriptase motifs in the catalytic subunit of telomerase. Science 276: 561-567.

Martin, G.M., C.A. Sprague, and C.J. Epstein. 1970. Replicative life-span of cultivated human cells. Effects of donor's age, tissue, and genotype. Lab. Invest. 23: 86-92.

Meyerson, M., C.M. Counter, E.N. Eaton, L.W. Ellisen, P. Steiner, S.D. Caddle, L. Ziaugra, R.L. Beijersbergen, M.J. Davidoff, Q. Lui, S. Bacchetti, D.A. Haber, and R.A. Weinburg. 1997. hEST2, the putative human telomerase catalytic subunit gene, is up-regulated in tumor cells and during immortalization. Cell 90: 785-795.

Morgenstern, J.P. and H. Land. 1990. Advanced mammalian gene transfer: High titre retroviral vectors with multiple drug selection markers and a complementary helper-free packaging cells line. Nucleic Acids Res. 18: 3587-3596.

Morin, G.B. 1989. The human telomere transferase enzyme is a ribonucleoprotein that synthesizes TTAGGG repeats. Cell 59: 521-529.

Moyzis, R.K., J.M. Buckingham, L.S. Cram, M. Dani, L.L. Deaven, M.D.M. Jones, R.L. Ratliff, and J.R. Wu. 1988. A highly conserved repetitive DNA sequence, (TTAGGG)n, present at the telomeres of human chromosomes. Proc. Nat1. Acad. Sci. 85: 6622-6626.

Nakamura, T.M., G.B. Morin, K.B. Chapman, S.L. Weinrich, W.H. Andrews, J. Lingner, C.B. Harley, and T.R. Cech. 1997. Telomerase catalytic subunit homologs from fission yeast and humans. Science 277: 955-959.

Nakayama, J.-I., M. Saito, H. Nakamura, A. Matsuura, and F. Ishikawa. 1997. TLP1: A gene encoding a protein component of mammalian telomerase is a novel member of WD repeats family. Cell 88: 1-20.

Norton, J.C., L.S. Gollahon, S.E. Holt, W.E. Wright, and J.W. Shay. 1997. Enhanced detection of telomerase activity from human cells and tumors. DNA Cell Biol. 17: 217-219.

Olovnikov, A.M. 1973. A theory of marginotomy. The incomplete copying of template margin in enzymic synthesis of polynucleotides and biological significance of the phenomenon. J. Theor. Biol. 41: 181-190.

Pratt, W.B. and D.O. Toft. 1997. Steroid receptor interactions with heat shock protein and immunophilin chaperones. Endocr. Rev. 18: 306-360.

Prodromou, C., S.M. Roe, R. O'Brien, J.E. Ladbury, P.W. Piper, and L.H. Pearl. 1997. Identification and structural characterization of the ATP/ADP-binding site in the hsp90 molecular chaperone. Cell 90: 65-75.

Schneider, E.L. and Y. Mitsui. 1976. The relationship between in vitro cellular aging and in vivo human age. Proc. Nat1. Acad. Sci. 73: 3584-3588. 
Holt et al.

Schumacher, R.J., R. Hurst, W.P. Sullivan, N.J. McMahon, D.O. Toft, and R.L. Matts. 1994. ATP-dependent chaparoning activity of reticulocyte lysate. J. Biol. Chem. 269: 9493-9499.

Schumacher, R.J., W.J. Hansen, B.C. Freeman, E. Alnemri, G. Litwack, and D.O. Toft. 1996. Cooperative action of hsp70, hsp90, and DnaJ proteins in protein renaturation. Biochemistry 35: 14889-14898.

Sullivan, E.S., B. Stensgard, G. Caucutt, B. Bartha, N. McMahon, E.S. Alnemri, G. Litwack, and D. Toft. 1997. Nucleotides and two functional states of hsp90. I. Biol. Chem. 272: 8007-8012.

Taylor, R.S., R.D. Ramirez, M. Ogoshi, M. Chaffins, M.A. Piatyszek, and J.W. Shay. 1996. Detection of telomerase activity in malignant and nonmalignant skin conditions. I. Invest. Dermatol. 106: 759-765.

Toft, D.O. 1998. Recent advances in the study of hsp90 structure and mechanism of action. Trends Endocrinol. Metab. 9: $238-243$.

Vaziri, H. and S. Benchimol. 1998. Reconstitution of telomerase activity in normal human cells leads to elongation of telomeres and extended replicative life span. Curr. Biol. 8: 279282.

Vaziri, H., F. Schachter, I. Uchida, L. Wei, X. Zhu, R. Effros, D. Cohen, and C.B. Harley. 1993. Loss of telomeric DNA during aging of normal and trisomy 21 human lymphocytes. Am. J. Hum. Genet. 52: 661-667.

Vojtek, A.B., S.M. Hollenberg, and J.A. Cooper. 1993. Mammalian Ras interacts directly with the serine/threonine kinase Raf. Cell 74: 205-214.

Watson, J.D. 1972. Origin of concatameric T4 DNA. Nature 239: 197-201.

Weinrich, S.L., R.l. Pruzan, L. Ma, M. Ouellette, V.M. Tesmer, S.E. Holt, A.G. Bodnar, S. Lichtsteiner, N.W. Kim, J.B. Trager, R.B. Taylor, R. Carlos, W.H. Andrews, W.E. Wright, J.W. Shay, C.B. Harley, and G.B. Morin. 1997. Reconstitution of human telomerase with the template RNA component hTR and the catalytic protein subunit hTRT. Nat. Genet. 17: 498-502.

Wright, W.E., M.A. Piatyszek, W.E. Rainey, W. Byrd, and J.W. Shay. 1996. Telomerase activity in human germline and embryonic tissues. Dev. Genet. 18: 173-179.

Wright, W.E., V.M. Tesmer, K.E. Huffman, S.D. Levene, and J.W. Shay. 1997. Normal human chromosomes have long G-rich telomeric overhangs at one end. Genes \& Dev. 11: 2801-2809. 


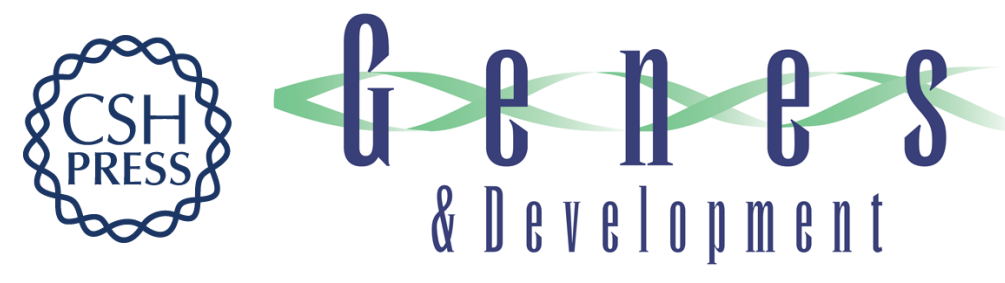

\section{Functional requirement of p23 and Hsp90 in telomerase complexes}

Shawn E. Holt, Dara L. Aisner, Joseph Baur, et al.

Genes Dev. 1999, 13:

References This article cites 54 articles, 27 of which can be accessed free at: http://genesdev.cshlp.org/content/13/7/817.full.html\#ref-list-1

License

Email Alerting

Receive free email alerts when new articles cite this article - sign up in the box at the top Service right corner of the article or click here.

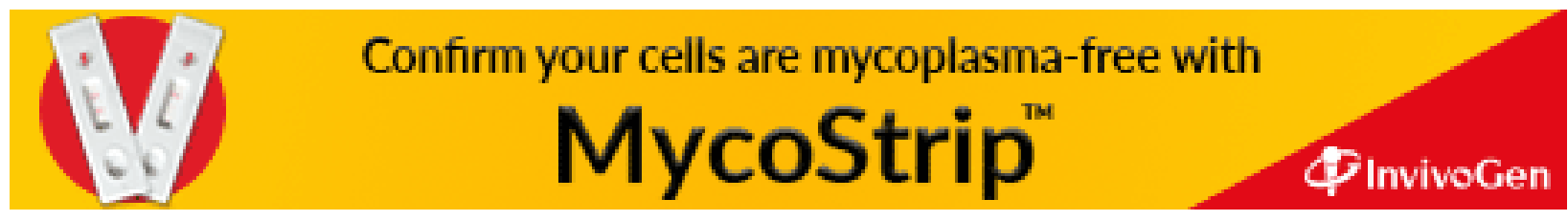

